\title{
Dualisme Pengaturan Ojek Online Angkut Penumpang dalam Pembatasan Sosial Berskala Besar (PSBB) di Jakarta
}

\author{
Hartanto dan Nidya Tajsgoani \\ Fakultas Hukum, Universitas Widya Mataram Yogyakarta, Indonesia \\ Email: hartanto.mhum@yahoo.com
}

\begin{abstract}
Abstrak
Ketergantungan masyarakat terhadap transportasi ojek online sangat luar biasa karena ojek online praktis dan dapat menjamin adanya hubungan antara ojek online dengan perusahaan trasportasi online. Larangan ojek online angkut penumpang dalam rangka menghindari penyebaran Covid - 19 dilakukan sebagai upaya memutus mata rantai penyebaran Covid - 19. Penelitian ini menggunakan metode yuridis normatif. Penelitian ini membahas mengenai problematika dualisme peraturan Peraturan Menteri Perhubungan Nomor 18 Tahun 2020 tentang Pengendalian Transportasi dalam Rangka Pencegahan Penyebaran Corona Virus Disease 2019 (Covid - 19) dengan Peraturan Kementerian Kesehatan dan Peraturan Gubernur. Peraturan Menteri Perhubungan Nomor 18 Tahun 2020 ini dibuat untuk kebutuhan nasional, dimana tiap daerah memiliki karakteristik wilayah dan kebutuhan transportasi yang berbeda-beda yang perlu tetap diakomodir serta dalam implementasinya pemerintah daerah diberikan kewenangan sesuai dengan ketentuan yang ada dan protokol kesehatan. Pengaturan transportasi ojek online merupakan kewenangan kementerian perhubungan, akan tetapi dengan terjadinya kegentingan penyebaran pandemik Covid - 19 seyogyanya berpedoman pada Peraturan Kementerian Kesehatan sehingga tidak menimbukan polemik di dalam masyarakat dan sistem birokrasi ketatanegaraan di Indonesia.
\end{abstract}

\section{Kata Kunci: Dualisme, Pengaturan, Ojek Online, PSBB}

\section{Abstract}

The dependency of the community on online motorcycle taxi transportation is extraordinary in terms of practicality and can guarantee a connection between online motorcycle taxi and online transportation companies. Ban on online motorcycle taxi transporting passengers in order to avoid the spread of covid 19 was carried out as an effort to break the chain of distribution of covid 19. This study used a normative juridical method. In this study discusses the problem of dualism of regulation of the Minister of Transportation Regulation No. 18 of 2020 concerning Transportation Control in the Prevention of Spreading Corona Virus Disease 2019 (Covid-19) with the regulations of the ministry of health and governor's regulations. Regulation of the Minister of Transportation No. 18 of 2020 is made for national needs, where each region has different regional characteristics and transportation needs that need to be accommodated and in its implementation the local government is given authority in accordance with existing 
provisions and health protocols. Online ojek transportation arrangements are the authority of the ministry of transportation but with the emergence of the urgency of the spread of the pvidemic covid 19 it should be guided by the regulation of the ministry of health so that it does not incur polemic in the community and the state bureaucratic system in Indonesia.

\section{Keywords: Dualism, Regulation, Ojek Online, PSBB}

\section{A. Pendahuluan}

Indonesia menganut konsep negara kesejahteraan, sebenarnya tekad negara Indonesia untuk mewujudkan kesejahteraan umum. ${ }^{1}$ Lebih lanjut Sjachran Basah mengemukakan bahwa jika ada kewajiban pemerintahan untuk memajukan kesejahteraan umum untuk merupakan ciri konsep kesejahteraan, Indonesia tergolong sebagai negara kesejahteraan, karena tugas pemerintah tidaklah semata-mata hanya di bidang pemerintahan saja, melainkan harus juga melaksanakan kesejahteraan sosial dalam rangka mencapai tujuan negara yang dijalani melalui pembangunan nasional. ${ }^{2}$

Pemerintah diperhadapkan permasalahan pandemik virus corona atau Covid - 19. Hal ini merupakan tantangan besar pemerintah Indonesia untuk tetap menciptakan negara welfare state. Covid - 19 merupakan tantangan yang sangat besar berkaitan dengan permasalah ekonomi dan pendemik ini. Virus Corona atau severe acute respiratory syndrome coronavirus 2 (SARS-CoV2) adalah virus yang menyerang sistem pernapasan. Penyakit karena infeksi virus ini disebut Covid - 19. Virus Corona dapat menyebabkan gangguan pada sistem pernapasan, pneumonia akut, sampai kematian. Severe acute respiratory syndrome coronavirus 2 (SARS-CoV-2) yang lebih dikenal dengan nama virus Corona adalah jenis baru dari coronavirus yang menular ke manusia. Virus ini dapat menyerang siapa saja, baik bayi, anak-anak, orang dewasa, lansia, ibu hamil, maupun ibu menyusui. Penyebaran corona virus atau Covid - 19

\footnotetext{
${ }^{1}$ Philipus M. Hadjon, 2007, Perlindungan Bagi Rakyat di Indonesia, Edisi Revisi, Peradaban, Jakarta, hlm. 91.

${ }^{2}$ Sjachran Basah, 1985, Eksistensi dan Tolok Ukur Badan Peradilan Administrasi di Indoenesia, Bandung, Alumni, hlm. 3.
} 
menyebabkan lumpuhnya perekonomian dan ada beberapa daerah yang melakukan local lockdown atau karantina wilayah sebagai bagian pemutusan mata rantai penyebaran Covid - 19 ini. $^{3}$

Pemerintah mengambil upaya PSBB yang akan dilakukan berkala di setiap daerah seiring dengan semakin meluasnya penyebaran Covid - 19 . PSBB diterapkan melihat tingginya tingkat penyebaran pandemik Covid - 19 yang terjadi di beberapa daerah metropolitan salah satunnya Jakarta. Pemerintah Jakarta atau Gubernur mengeluarkan kebijakan yang sangat berkaitan dengan permasalahan penanganan pandemik Covid - 19 ini, kebijakan tersebut berupa larangan ojek online untuk angkut penumpang yang dianggap sangat merugikan pengguna aplikasi yang mengantungkan hidup dari transportasi online tersebut.

Kebijakan ini dilaksanakan untuk memutus penyebaran virus corona Covid - 19. Pertimbangannya jelas, pertama, pengemudi ojek dapat menjadi orang yang rawan tertular oleh Covid - 19 dari penumpang yang positif terinveksi Covid-19. Kedua, pengemudi ojek online dapat menjadi pembawa virus atau carrier, baik dari penumpang yang diangkut bawa maupun barang yang pengemudi antarkan. Ketiga, pengemudi yang sudah tertular Covid - 19 juga dapat menularkan kepada penumpang maupun keluarga di rumah.

Ojek online kini telah menjadi sebuah fenomena luar biasa, terutama bagi masyarakat yang berada di kota - kota besar yang merasakan langsung dampak dari keberadaan ojek online tersebut. Pertumbuhan bisnis ojek berbasis online ini dalam perkembangannya diikuti dengan makin meningkatnya animo masyarakat. Hal ini ditandai dengan jumlah pengunduh

\footnotetext{
${ }^{3}$ Alodokter, Severe Acute Respiratory Syndrome Coronavirus 2 (SARS - CoV - 2), https://www.alodokter.com/virus-corona, dikases tanggal 3 April 2020.
} 
aplikasi yang telah mencapai jutaan orang pengunduh. ${ }^{4}$ Ketergantungan masyarakat terhadap transportasi ini sangat luar biasa dikarenakan praktis dan dapat menjamin karena adanya hubungan antara ojek online dengan perusahaan trasportasi online sehingga masyarat lebih mudah melakukan complain apabila merasa dirugikan melalui aplikasi tersebut dan sanksi yang sangat tegas. Banyak ojek online yang mengantungkan hidup pada aplikasi ini untuk dapat menafkahi anak dan keluargannya sehingga harus dipertimbangakan mengenai kesejahteraan seperti halnya dituangkan dalam amanah UUD NRI 1945 dan tanggung jawab negara Welfare State terhadap kesejahteraan warganya apabila PSBB dilakukan.

Kebijakan yang dikeluarkan oleh pemerintah Jakarta sesuai dengan Peraturan Menteri Kesehatan Nomor 9 Tahun 2020 tentang Pedoman Pembatasan Sosial Berskala Besar dalam Rangka Percepatan Penanganan Corona Virus Disease 2019 (Covid - 19). Munculnya polemik baru di tengah masyarakat setelah dikeluarkannya Peraturan Menteri Perhubungan Nomor 18 Tahun 2020 tentang Pengendalian Transportasi dalam Rangka Pencegahan Penyebaran Covid - 19 justru mengendurkan dua aturan yang sudah ada sehingga menuai kontroversi. Pasal 11 Ayat (1) huruf c menyebutkan: "Sepeda motor berbasis aplikasi dibatasi penggunaannya hanya untuk pengangkutan barang" sementara di pasal yang sama, huruf (d) menyebutkan "dalam hal tertentu untuk tujuan melayani kepentingan masyarakat dan untuk kepentingan pribadi, sepeda motor dapat mengangkut penumpang dengan ketentuan harus memenuhi protokol kesehatan. Berbagai kebijkan ini sangat menuai kontroversi dimana pemerintah dianggap tidak konsisten dan menunjukan ketidakkompakan dalam menyelesaikan pandemik Covid - 19 ini.

${ }^{4}$ Sonhaji, “Aspek Hukum Layanan Ojek Online Perspektif Undang - Undang Nomor 13 Tahun 2003 tentang Ketenagakerjaan”, Adminitrative Law \& Governance Journal, Vol. 1 Edisi 4, November, 2018, hlm. 372. 


\section{B. Metode Penelitian}

Metode penelitian ini yang digunakan oleh penulis dalam penulisan ini adalah penelitian hukum normatif, yaitu penelitian hukum doktriner, juga disebut sebagai penelitian perpustakaan atau studi dokumen. Disebut penelitian hukum doktriner, karena penelitian ini dilakukan atau ditujukan hanya pada peraturan-peraturan yang tertulis atau bahan-bahan hukum yang lain, sebagai penelitian perpustakaan atau studi dokumen disebabkan penelitian ini banyak dilakukan terhadap data yang bersifat sekunder yang ada di perpustakaan ${ }^{5}$. Sehubungan dengan tipe penelitiannya yuridis normatif maka pendekatan yang digunakan adalah pendekatan hukum yang berlaku di Indonesia (hukum positif). Suatu analisis pada hakekatnya menekankan pada metode deduktif sebagai pegangan utama, dan metode induktif sebagai tata kerja penunjang.analisis normatif mempergunakan bahan-bahan kepustakaan sebagai sumber data penelitiannya. ${ }^{6}$ Data yang diperoleh akan diolah dan dianalisis secara kualitatif, selanjutnya data tersebut dideskriptifkan dalam artian bahwa data akan menjelaskan, menguraikan, dan menggambarkan permasalahan dengan penyelesaian berkaitan dengan penulisan ini.

\section{Pembahasan}

\section{Pengaturan Ojek Online Angkut Penumpang Pembatasan Sosial} Berskala Besar (PSBB) di Jakarta.

Pengangkutan merupakan suatu bentuk kegiatan yang sangat penting dalam kehidupan masyarakat. Kegiatan pengangkutan didasari oleh berbagai faktor, baik faktor geografis, faktor pemenuhan kebutuhan untuk menunjang pembangunan berbagai sektor berupa penyebaran, pemerataan dan pendistribusian hasil pembangunan ke seluruh pelosok 14.

${ }^{5}$ Bambang Waluyo, 2008, Penelitian Hukum dalam Praktek, Jakarta, Sinar Grafika, hlm. Grafindo, hlm. 16. 
tanah air, serta faktor perkembangan ilmu pengetahuan dan teknologi. ${ }^{7}$ Tujuan dari proses pengangkutan itu sendiri adalah pemindahan orang atau barang dari suatu tempat ke tempat lain dengan menggunakan alat angkut untuk memenuhi kebutuhan perseorangan atau pribadi, yaitu agar tiba di tempat tujuan dengan selamat dan meningkatkan nilai guna atau nilai tukar dari barang atau orang yang diangkut. ${ }^{8}$

Alat transportasi berbasis aplikasi yang sedang berkembang pada saat ini berupa angkutan taksi online dan ojek online. Perusahaan penyedia aplikasi yang dapat ditemui di Indonesia pada saat ini adalah PT. GO-JEK dan PT. GRAB Indonesia. Pemesanan angkutan berbasis aplikasi online dapat dilakukan oleh calon penumpang dengan memesan angkutan yang diinginkan melalui sebuah apikasi yang dapat diunduh pada handphone yang milik customer. Aplikasi yang digunakan untuk memesan alat transportasi online telah terintegrasi dengan perusahaan aplikasi online. Saat melakukan proses pemesan alat transportasi online, calon penumpang harus mengisi lokasi penjemputan, tempat tujuan serta moda transportasi yang diinginkan. Setelah informasi diterima, maka perusahaan aplikasi online tersebut akan menghubungkan informasi yang telah diinput pada aplikasi kepada para driver yang tergabung dalam perusahaan transportasi online tersebut. Aplikasi tersebut termuat informasi seperti identitas pengemudi, nomor polisi kendaraan pengemudi, nomor telepon ojek online yang dapat dihubungi, jumlah tarif perjalanan yang harus dibayar. Selain itu, customer dapat mengetahui perkembangan posisi ojek online yang

${ }^{7}$ Abdul Kadir Muhammad, 1991, Hukum Pengangkutan Darat, Laut, dan Udara, Jakarta, Citra Aditya Bakti, hlm. 30.

${ }^{8}$ Wuri Adriyani dan Samzari Boentoro, 2007, Buku Ajar Hukum Pengangkutan, Surabaya, Universitas Airlangga, hlm. 1. 
akan menuju titik penjemputan secara langsung melalui fitur pelacak posisi. $^{9}$

PSBB dilaksanakan sebagai upaya menghindari penyebaran Covid - 19. Pemerintah pusat melalui Kementerian Kesehatan dan Pemerintah Provinsi melalui Gubernur mengeluarkan Peraturan Menteri Kesehatan Nomor 9 Tahun 2020 tentang Pedoman Pembatasan Sosial Berskala Besar dalam Rangka Percepatan Penanganan Corona Virus Disease 2019 Covid - 19 dan Peraturan Gubernur DKI Jakarta Nomort 33 Tahun 2020 tentang Pelaksanaan Pembatasan Sosial Berskala Besar dalam Penanganan Corona Virus Disease 2019 (Covid - 19) di Provinsi Daerah Khusus Ibukota Jakarta.

Peraturan Menteri Kesehatan Nomor 9 Tahun 2020 tentang Pedoman Pembatasan Sosial Berskala Besar dalam Rangka Percepatan Penanganan Corona Virus Disease 2019 (Covid - 19) mengatur kategori Perusahaan komersial dan swasta yakni pada lampiran D) tentang Pelaksanaan Pembatasan Sosial Berskala Besar, pada angka 2) soal perusahaan swasta yang dikecualikan yakni pada huruf i) Permenkes itu menyebutkan, "Layanan Ekspedisi barang, termasuk sarana angkutan roda dua, berbasis aplikasi dengan batasan hanya untuk mengangkut barang, dan tidak untuk penumpang." Salah satu pertimbangan larangan ojek online mengangkut penumpang bertujuan untuk melindungi pengemudi ojek online itu sendiri. Sebab driver harus melayani berbagai lapisan masyarakat yang keadaannya tidak ketahui apakah sendang sehat atau terinfeksi Covid $-19$.

Kebijakan ini dilaksankan guna memutus penyebaran Covid - 19 . Pertimbangannya jelas, pertama, pengemudi ojek online bisa saja menjadi

${ }^{9}$ Nuraini Fillaili, “Tanggung Jawab Perusahaan Transportasi Online terhadap Penumpang Akibat Adanya Praktik Peralihan Akun", Jurist-Diction, Vol. 2, No. 4, Juli, 2019, hlm. 1377. 
orang yang rawan tertular oleh Covid - 19 dari penumpang yang positif terinfeksi Covid - 19. Kedua, pengemudi ojek online bisa menjadi pembawa virus atau carrier, baik dari penumpang yang dibawa maupun barang yang diantarkan. Ketiga, pengemudi yang sudah tertular Covid - 19 juga dapat menularkan kepada penumpang maupun keluarga di rumah.

Pembatasan dilakukan oleh driver amupun pengguna transportasi online dikarenakan aktivitas transpotasi online khususnya driver sangat berisiko terinfeksi virus ataupun menularkan virus kepada penumpangnya. Selain itu, penumpang yang terkena virus juga dapat lebih mudah menularkan virus kepada ojek online, dan ojek online kepada keluarga dan keluarga dapat menularkan virus kepdan tetangga dan orang terdekat, dan seterusnya. Langkah ini dilakukan sebagai upaya memutus mata rantai penyebaran Covid - 19.

Ojek online tetap dapat melakukan aktivitas untuk tetap melakukan pekerjaannya untuk menghidupi keluarganya. Akan tetapi, problematika yang harus diamati ketika hal ini dilakukan adalah pengguna tranportasi online hampir $80 \%$, ditambah lagi adanya pembatasan aktivitas serta banyaknya driver yang membutuhkan penghidupan yang mengakibatkan pendapatan menurun. Perlu suatu kajian agar setiap ojek online dapat menghidupi keluarga di tengah kondisi pandemik ini. Lebih lanjut, ditegaskan oleh Niewenhuis bahwa prinsip - prinsip hukum tanggungjawab berfungsi sebagai pembentuk produk hukum karena tidak hanya mempengaruhi hukum positif melainkan sistem yang baik sehingga hukum yang baik tidak akan ada tanpa adanya prinsip - prinsip tanggungjawab yang dituangkan dalam produk hukum. ${ }^{10}$ Berdasarkan uraian di atas, posisi prinsip hukum sebagai meta norma hukum pada dasarnya memberikan arah

${ }^{10}$ Yohanes Sogar Simamora, 2009, Hukum Perjanjian Prinsip Hukum Kontrak Pengadaan Barang dan Jasa Oleh Pemerintah, Laksbang Pressindo, Yogyakarta, hlm 36-37. 
tujuan serta penilaian fundamental bagi keberadaan suatu norma hukum sehingga kebijakan pemerintah yang diambil tetap memenuhi prinsip tanggungjawab dalam pelaksanaan PSBB.

\section{Problematika Pengaturan Ojek Online Angkut Penumpang dalam Pembatasan Sosial Berskala Besar (PSBB) di Jakarta}

UUD NRI 1945 menentukan dengan tegas bahwa negara Indonesia adalah negara hukum. Sebagai Negara yang berdasar atas hukum segala sendi-sendi kehidupan berbangsa dan bernegara haruslah didasarkan atas hukum. Meski negara Indonesia adalah negara hukum, tetapi cara menginterpretasikan hukum itu bukanlah sekadar hukum yang tertulis, utamanya harus didukung oleh pribadi - pribadi yang berbudi pekerti luhur untuk memobilisasi hukum agar hukum dapat berjalan sesuai fungsinya. Keberadaan Moda Transportasi berbasis online saat ini adalah salah satu solusi untuk mengatasi pengangguran. Manfaatnya nyata dirasakan oleh masyarakat. Hukum itu tidak seyogyanya dibaca hanya secara teks redaksional semata, hukum harus dimaknai secara terintegrasi, holistik dan komprehensif. ${ }^{11}$

Pelayanan publik termasuk jasa transportasi adalah tanggungjawab pemerintah sebagaimana ditentukan Pasal 1 angka 1 dan angka 2 Undang Undang Nomor 25 Tahun 2009 tentang Pelayanan Publik sebagai berikut: Pelayanan publik adalah kegiatan atau rangkaian kegiatan dalam rangka pemenuhan kebutuhan pelayanan sesuai dengan peraturan perundang undangan bagi setiap warga negara dan penduduk atas barang, jasa, dan/atau pelayanan administratif yang disediakan oleh penyelenggara pelayanan publik. Penyelenggara pelayanan publik yang selanjutnya disebut Penyelenggara adalah setiap institusi penyelenggara negara, korporasi,

${ }^{11}$ Prosiding Seminar Nasional Multi Disiplin Ilmu \&Call For Papers Unisbank Ke-3 (Sendi - U 3) 2017 ISBN: 9-789-7936-499-93, hlm 410. 
lembaga independen yang dibentuk berdasarkan undang - undang untuk kegiatan pelayanan publik, dan badan hukum lain yang dibentuk semata mata untuk kegiatan pelayanan publik.

Problematika muncul setelah adanya penyebaran Covid - 19 dimana pemerintah menetapkan PSBB sebagai langkah revolusioner dalam memutus mata rantai penyebarannya dengan mengeluarkan Peraturan Menteri Kesehatan Nomor 9 Tahun 2020 tentang Pedoman PSBB. Disebutkan bahwa dalam penerapannya, ojek berbasis aplikasi hanya boleh beroperasi untuk mengantar barang, artinya tidak boleh membawa penumpang. ${ }^{12}$ Pasal 11 huruf (c) dijelaskan bahwa angkutan roda berbasis aplikasi dibatasi penggunaannya hanya untuk pengangkutan barang. Artinya, ojek online tidak boleh membawa penumpang dan hanya untuk barang sesuai dengan ketetapan yang ada. Namun, pasal yang sama pada huruf (d) dijelaskan bahwa dalam hal tertentu untuk tujuan melayani kepentingan masyarakat dan untuk kepentingan pribadi, sepeda motor dapat mengangkut penumpang dengan ketentuan harus memenuhi protokol kesehatan. Protokol kesehatan yang dimaksud meliputi:

1. Aktivitas lain yang diperbolehkan selama PSBB

2. Melakukan disinfeksi kendaraan dan perlengkapan sebelum dan setelah selesai digunakan

3. Menggunakan masker dan sarung tangan

4. Tidak berkendara jika sedang mengalami suhu badan di atas normal atau sakit

Problematika ini muncul setelah adanya Peraturan Menteri Perhubungan Nomor 18 Tahun 2020 tentang Pengendalian Transportasi dalam Rangka Pencegahan Penyebaran Corona Virus Disease 2019 (Covid

${ }^{12}$ Penjelasan Kemenhub Izinkan Ojol Angkut Penumpang Saat PSBB Jakarta, https://otomotif.kompas.com/read/2020/04/13/082200715/penjelasan-kemenhub-izinkan-ojolangkut-penumpang-saat-psbb-jakarta, dikases tanggal 3 April 2020. 
- 19). Peraturan ini menuai banyak kontroversi dan melemahkan Peraturan Menteri Kesehatan dan Peraturan Gubernur yang dapat dilihat dalam Pasal 11 ayat (1) huruf (c) yang menyebutkan: "Sepeda motor berbasis aplikasi dibatasi penggunaannya hanya untuk pengangkutan barang". Sementara di pasal yang sama, huruf (d) menyebutkan "dalam hal tertentu untuk tujuan melayani kepentingan masyarakat dan untuk kepentingan pribadi, sepeda motor dapat mengangkut penumpang dengan ketentuan harus memenuhi protokol kesehatan." Pasal dalam aturan ini mengabaikan Peraturan Menteri Kesehatan dan Peraturan Gubernur menunjukan ketidakpercayaan dan tidak adanya kekompakan dalam pelaksanaan birokrasi guna memutus mata rantai penyebaran Covid - 19 .

Kementerian Perhubungan akhirnya melarang ojek online membawa penumpang di saat penerapan PSBB di sejumlah daerah. Hal tersebut ditetapkan setelah Kementerian Kesehatan dan Kementerian Perhubungan menyepakati klausul terkait pengaturan sepeda motor, harus mengikuti ketentuan sesuai Pasal 11 ayat (1) huruf c yaitu sepeda motor berbasis aplikasi dibatasi hanya untuk mengangkut barang. Adapun klausul dalam pasal 11 ayat (1) huruf d dinyatakan bahwa dalam hal tertentu sepeda motor dapat membawa penumpang dengan ketentuan harus memenuhi protokol kesehatan. Perlu diingat bahwa Peraturan Menteri Perhubungan Nomor 18 Tahun 2020 ini dibuat untuk kebutuhan nasional, dimana tiap daerah memiliki karakteristik wilayah dan kebutuhan transportasi yang berbeda beda yang perlu tetap diakomodir.

Peratuan Gubernur ini dianggap bersifat khusus yakni dalam rangka mempercepat penanganan wabah Covid - 19. Peraturan Gubernur sebagai aturan lebih teknis dan kewilayahan sehingga dapat diartikan sebagai aturan yang bersifat lex specialist dibandingkan dengan dua peraturan kementrian tersebut, selama tidak bertentangan dengan peraturan di atasnya. 
Pemerintah Pusat maupun Pemerintah Daerah sejatinya tegas melarang aktivitas ojek berbasis aplikasi atau ojek online untuk mengangkut penumpang selama pemberlakuan kebijakan Pembatasan Sosial Berskala Besar (PSBB). ${ }^{13}$ Selain itu, pengaturan sepeda motor dinggap tidak bertentangan dengan prinsip prinsip Lex Superior derogat Legi Inferior, dimana prinsip ini menyatakan bahwa setiap peraturan perundang undangan yang lebih tinggi mengesampingkan peraturan perundang undangan yang lebih rendah. Prinsip ini dituangkan juga di dalam penjelasan Undang - Undang Nomor 12 Tahun 2011 tentang Pembentukan Peraturan Perundang - Undangan, yang menyatakan:

Dalam ketentuan ini yang dimaksud dengan "hierarki" adalah penjenjangan setiap jenis Peraturan Perundang-undangan yang didasarkan pada asas bahwa Peraturan Perundang-undangan yang lebih rendah tidak boleh bertentangan dengan Peraturan Perundangundangan yang lebih tinggi.

Hal ini dapat dilihat dalam Pasal 11 Ayat (1) huruf c Peraturan Menteri Perhubungan Nomor 18 Tahun 2020 tentang Pengendalian Transportasi dalam Rangka Pencegahan Penyebaran Corona Virus Disease 2019 (Covid - 19) yang menjelaskan mengenai sepeda motor berbasis aplikasi dibatasi hanya untuk mengangkut barang. Pasal 11 Ayat (1) huruf d yang menyatakan bahwa dalam hal tertentu sepeda motor dapat membawa penumpang dengan ketentuan harus memenuhi protokol kesehatan, disepakati bahwa keputusan implementasinya akan dikembalikan kepada Pemerintah Daerah. ${ }^{14}$ Aturan ini memberikan amanah kepada pemerintah daerah dalam mengatur daerahnya. Pemerintah daerah menurut amanah ini bertanggung jawab dalam pelaksanaan PSBB menurut Ridwan Halim

${ }^{13}$ Ojek Online di Jakarta Diatur Gubernur Anies Dan Dua Menteri, Mana yang Dipatuhi, https://regional.kontan.co.id/news/operasional-ojol-di-jakarta-diatur-dua-menteri-dan-gubernuranies-mana-yang-dipatuhi?page=all, diakses tanggal 5 April 2020.

${ }^{14}$ Pro Kontra Permenhub soal Kewenangan Ojek Online Angkutan Penumpang, https://kliklegal.com/pro-kontra-permenhub-no-18-2020-soal-kewenangan-ojek-online-angkutpenumpang-saat-psbb/, diakses tanggal 5 April 2020. 
tanggung jawab pemerintah daerah sebagai sesuatu akibat lebih lanjut dari pelaksanaan peranan, baik peranan itu merupakan hak dan kewajiban ataupun kekuasaan. Tanggung jawab pemerintah daerah yang diartikan sebagai kewajiban untuk melakukan sesuatu atau berperilaku menurut cara tertentu tidak menyimpang dari peraturan yang telah ada. ${ }^{15}$

Selain itu, perusahaan transportasi online juga ikut berpartisipasi dalam menekan penyebarluasan virus dengan membuat suatu kebijakan dengan menghapus fitur salam aplikasi untuk menganggung penumpang, akan tetapi masih banyak ditemukan ojek online yang mengangkut penumpang dengan tidak mengunakan aplikasi online setidaknya terdapat 339 pengemudi yang tetap mengangkut penumpang pada masa PSBB, berdasarkan data yang dihimpun Kompas edisi Senin, 20 April 2020. Untuk itu perlunya satu regulasi yang tegas dalam penanganan hal ini dari pihak perusahaan trasportasi dan pemerintah.

Pengaturan transportasi online merupakan kewenangan Kementerian Perhubungan. Akan tetapi, dengan terjadinya kegentingan penyebaran pandemik Covid - 19 seyogyannya berpedoman Peraturan Kementerian Kesehatan sehingga tidak menimbukan polemik di dalam masyarakat dan sistem birokrasi ketatanegaraan di Indonesia.

\section{Penutup}

Peraturan PSBB diatur dalam Peraturan Menteri Kesehatan Nomor 9 Tahun 2020 tentang Pedoman Pembatasan Sosial Berskala Besar dalam Rangka Percepatan Penanganan Corona Virus Disease 2019 (Covid - 19) dan Peraturan Gubernur DKI Jakarta Nomor 33 Tahun 2020 tentang Pelaksanaan Pembatasan Sosial Berskala Besar dalam Penanganan Corona Virus Disease 2019 (Covid - 19) di Provinsi Daerah Khusus Ibukota Jakarta. Pembatasan

\footnotetext{
${ }^{15}$ Khairunnisa, 2008, Kedudukan, Peran dan Tanggung Jawab Hukum Direksi, Medan, Pasca Sarjana, hlm. 4.
} 
dilakukan kepada ojek online karena sangat berisiko penularan Covid - 19 . Langkah ini dilakukan sebagai upaya memutus mata rantai penyebaran Covid -19 yang terjadi.

Problematika Peraturan Menteri Perhubungan Nomor 18 Tahun 2020 tentang Pengendalian Transportasi dalam Rangka Pencegahan Penyebaran Corona Virus Disease 2019 (Covid - 19) peraturan ini menuai banyak kontroversi dan melemahkan Peraturan Kementerian Kesehatan dan Peraturan Gubernur dapat dilihat dalam Pasal 11 Ayat (1) huruf (c) yang memperbolehkan angkut penumpang menjadi dualisme hukum dengan mengabaikan Peraturan Kementerian Kesehatan. Pengaturan transportasi online merupakan kewenangan Kementerian Perhubungan akan tetapi dengan terjadinya kegentingan penyebaran pandemik Covid - 19 seyogyannya berpedoman pada Peraturan Kementerian Kesehatan sehingga tidak menimbulkan polemik di dalam masyarakat dan sistem birokrasi ketatanegaraan di Indonesia.

\section{Daftar Pustaka}

\section{Buku}

Amirudin, Zainal Asikin, 2012, Pengantar Metode Penelitian Hukum, Raja Grafindo, Jakarta.

Basah, Sjachran, 1985, Eksistensi dan Tolok Ukur Badan Peradilan Administrasi di Indonesia, Alumni, Bandung.

E. Utrecht, 1988, Pengantar Hukum Administrasi Negara Indonesia, Pustaka Tinta Mas, Surabaya.

M. Hadjon, Philipus, 2007, Perlindungan Bagi Rakyat di Indonesia, Edisi Revisi, Peradaban, Jakarta.

Manan, Bagir, 1999, "Pemikiran Negara Berkonstitusi di Indonesia", Makalah Temu Ilmiah Nasional Memformat Indonesia Baru: Reformasi Hukum sebagai Fondasi Reformasi Total, Fakultas Hukum Universitas Padjajaran, Bandung.

Muhammad, Abdul Kadir, 1991, Hukum Pengangkutan Darat, Laut, dan Udara, Citra Aditya Bakti, Jakarta. 
Simamora, Yohanes Sogar, 2009, Hukum Perjanjian Prinsip Hukum Kontrak Pengadaan Barang dan Jasa Oleh Pemerintah, Yogyakarta, Laksbang Pressindo.

Waluyo, Bambang, 2008, Penelitian Hukum dalam Praktek, Sinar Grafika, Jakarta.

\section{Jurnal}

Fillaili, Nuraini, "Tanggung Jawab Perusahaan Transportasi Online terhadap Penumpang Akibat Adanya Praktik Peralihan Akun", Jurist-Diction, Vol. 2, No. 4, Juli, 2019.

Hartanto, "Eksistensi Deradikalisasi Dalam Konsep Pembebasan Bersyarat Bagi Narapidana Terorisme", Jurnal Jurisprudentie, Vol. 6, No. 1, Juni, 2019.

Khairunnisa, 2008, Kedudukan, Peran dan Tanggung Jawab Hukum Direksi, Medan, Pasca Sarjana.

Roni Sulistyanto Luhukay, "Indenpendensi Kekuasaan Kehakiman Pasca Amandemen UUD 1945 dan Relevansinya Bagi Penegakan Hukum Berkeadilan”, Jurnal Jurisprudentie, Vol. 6, No. 1, Juni, 2019.

Prosiding Seminar Nasional Multi Disiplin Ilmu \& Call For Papers Unisbank Ke-3 (Sendi_U 3) 2017 ISBN: 9-789-7936-499-93.

Tjitrawati, Aktieva Tri, "The Just Drug Distribution in The Perspective of Welfare State", Mimbar Hukum, Vol. 25, No. 3, Oktober, 2013.

Sonhaji, "Aspek Hukum Layanan Ojek Online Perspektif Undang - Undang Nomor 13 Tahun 2003 tentang Ketenagakerjaan", Adminitrative Law \& Governance Journal, Vol. 1, Edisi 4, November, 2018.

\section{Internet}

Alodokter, Severe Acute Respiratory Syndrome Coronavirus 2 (SARS - CoV - 2), https://www.alodokter.com/virus-corona, dikases tanggal 3 April 2020.

Penjelasan Kemenhub Izinkan Ojol Angkut Penumpang Saat PSBB Jakarta, https://otomotif.kompas.com/read/2020/04/13/082200715/penjelasan-

kemenhub-izinkan-ojol-angkut-penumpang-saat-psbb-jakarta, dikases tanggal 3 April 2020.

Ojek Online di Jakarta Diatur Gubernur Anies Dan Dua Menteri, Mana yang Dipatuhi, $\quad$ https://regional.kontan.co.id/news/operasional-ojol-di-jakartadiatur-dua-menteri-dan-gubernur-anies-mana-yang-dipatuhi?page=all, diakses tanggal 5 April 2020.

Pro Kontra Permenhub soal Kewenangan Ojek Online Angkutan Penumpang, https://kliklegal.com/pro-kontra-permenhub-no-18-2020-soal-kewenanganojek-online-angkut-penumpang-saat-psbb/, diakses tanggal 5 April 2020. 